\title{
Determinants of Adolescent Childbearing in Oghara Kingdom, Delta State, Nigeria
}

\author{
Itimitang W. Etukudo \\ Nsidibe A. Usoro \\ Department of Sociology and Anthropology, University of Uyo, Nigeria
}

\begin{abstract}
Teenage pregnancy is an important health and Social problem in Nigeria. The study investigated the prevalence rate and the socio-economic factors that place adolescents at the high risk of early pregnancy in Oghara Kingdom. The respondents were 400 teenagers under 19years of age randomly selected from some villages in the two sub-clans of the kingdom. A structured interview schedule was used to obtain information used in the study. Frequencies, percentages and chi-square tests were used to analyse the data. The results of the study showed that the rate of teenage pregnancy in the study area was fairly high (66.2 percent). A large majority (87.3 percent) of the teenage pregnancies in the study area were unintended. Chi-square tests revealed associations between teenage pregnancy and respondents' education, sexual initiation, use of family planning, parents' wealth quintiles, wealth quintile of the person responsible for the pregnancy and place of abode before the pregnancy.

Keywords: Teenage pregnancy, Oghara Kingdom, Socio-economic factors, Nigeria

DOI: $10.7176 / \mathrm{JCSD} / 55-03$
\end{abstract}

Publication date: January $31^{\text {st }} 2020$

\section{INTRODUCTION}

Over the years, Nigeria has not witnessed any significant change in reproductive behaviour of women especially in the rural areas. Nigeria apart from being the most populous nation in Africa, is also the seventh most populous in the world (Population Reference Bureau, 2013). The total fertility rate (TFR) is 5.5 births per woman. It has an estimated national population growth rate of 3.2 per annum (United Nations Population Fund, 2014). Meanwhile, the contraceptive prevalence rate (CPR) among all women in Nigeria is 16 percent. The above information about the reproductive behaviour of women in Nigeria point to the fact that there are still many demographic challenges the country must overcome in order to witness a dramatic change in reproductive behaviour of women. One of such behaviour is adolescent childbearing or teenage pregnancy and motherhood. Globally, this is a major health concern (Senderowitz and Paxman, 1985).

In recent years, teenage pregnancy and teenage childbearing have captured a lot of research interest in both developed and developing countries because of its association with higher morbidity and mortality for both the mother and the child. While studies on fertility and contraceptive issues are enormous in Nigeria until recently, socioeconomic factors affecting adolescent childbearing has received very little attention among researchers and policy makers.

Some studies have shown that teenage fertility has negative economic, social and health consequences for young mothers as well as for their children (Kamal, 2012, Hayes, 1987, Gage, 1995). Women who become parents as teenagers are at greater risk of social and economic disadvantage throughout their lives than those who delay having children until their twenties. They are less likely to complete their Education, be employed, to earn high wages, and to be happily married (Haque, 2011; Kamal, 2012,. Kamal, 2012; Gogna et. al, 2008; Choe et. al. 2004; Gupta and Mahy, 2003; Hayes, 1987).

Long - term demographic effects of adolescent fertility may include larger completed family sizes. This is because the timing of the first birth is usually an indicator of future fertility patterns (Kamal, 2012; Wulf and Singh, 1991). Early marriage typically increases the risk of childbearing at a young age. Early pregnancy poses great health risks for a young woman and, if she carries the pregnancy to term, for her infant, these risks are exacerbated by poverty and inadequate access to maternal and child health services (Sing and Samara, 1996;

Worldwide, complications in pregnancy are the number one killer of girls and young women aged $15-19$. Every year 50,000 teenage girls and young women die during pregnancy and child-birth in many cases because their bodies are not ready to bear children (Rawe, 2012).

Babies born to young mothers are also at far greater risks than those whose mothers are older. Each year around one million babies born to adolescent girls die before their first birthday. In developing countries, if a mother is under 18 , her baby's chance of dying in the first year of life is $60 \%$ higher than that of a baby born to a mother older than 19 (UNICEF, 2006).

Many adolescent girls know little or nothing about family planning; let alone where to get it. Their low status within their families, communities and societies mean they lack the power to make their own decisions about whether or when to have a baby. No girl should die giving birth, and no child should die as a result of its 
mother being too young (Rawe, 2012).

Adolescent pregnancy carries high risks, both for the teenage girls and their babies. The risk of maternal death is twice as high for girls aged 15 to 19 as for women in their 20s, and five times higher for girls aged 10 to 14 (Population reference Bureau, 2009). Globally, around 50,000 teenage girls die each year during pregnancy and childbirth. About one million babies born to adolescent girls die before their first birthday (UNICEF, 2006). The proportion of still births and deaths in babies' first week of life are $50 \%$ higher among women under 20 , than among women aged $20-29$ (WHO, 2011a).Babies born to adolescent mothers account for $11 \%$ of all births worldwide; $95 \%$ occur in developing countries (WHO, 2011b).

Adolescent girls are more likely to give birth to premature babies and experience complications during labour, including heavy bleeding, infection and eclampsia because they are not physically ready for childbirth. (UNICEF, 2012). Their bodies are not fully developed and their pelvises are smaller, so they are more prone to suffer obstructed labour in the absence of emergency obstetric care. This can be deadly for both mother and baby (UNFPA, 2014; Gerommus and Korenman, 1992). Prolonged and obstructed labour can also cause great damage to an adolescent girl's body, leading to obstetric fistula (Rawe, 2012; Ihejiamaizu, 1991; Oladosu, 1989). Adolescent mothers and children are prone to anaemia and underweight; and they are prone to high risk of mortality and morbidity (NPC and ICF International, 2014; UNICEF, 2012; Betting et. al, 1998 Macweeney, 1985, Kappel-man,1977, Wasunna and Mohammed,2002; Zabin and Kiragu, 1998)

Compared with bodies of older mothers, those born to teenagers are more likely to have an increased risk of hospital admission in early childhood, less supportive home environments, poor cognitive development and, if female, has a higher risk or chance of becoming pregnant themselves as teenagers. (Betting et.al; 1998 and Wellings et.al; 1999). Young mothers are likely to be less educated and poor. (UNICEF, 2012). Women who become mothers in their teens have fewer educations and employment opportunities. They are more often socially isolated, poor and have mental health problems (Corcoran, 1998, Betting et.al; 1998 and Wellings et.al; 1999)

Teenage pregnancy is an important health and social problem in Nigeria. So far research on adolescent sexual activity has been almost exclusively descriptive; thus, there is considerable knowledge about sexual practices of adolescents in general and outcomes of their pregnancies, but very limited understanding of factors that place adolescents at increased risk of teenage pregnancy. This makes, our ability to intervene and reduce teenage pregnancy difficult. This study tries to fill this gap.

\section{OBJECTIVES}

The following are the objectives of the study:

1. to examine the pattern and prevalence rate of adolescent childbearing in the study area,

2. to identify the socio-economic determinants of adolescent childbearing in the study area

\section{SIGNIFICANCE}

It is hoped that the findings of this study can help policy makers to identify teenagers at risk of early pregnancy and also design some measures on how to deal with this problem in the study area in particular and other communities in general.

\section{STUDY AREA}

The study was conducted in Oghara kingdom. It is located in Ethiope West Local Government Area of Delta State, Nigeria with a population of over 90,000 people. The majority of the inhabitants belong to Urhobo ethnic group, with small proportions of people with other ethnic origins. The major occupations include farming, trading and lumbering and civil service work. Despite the presence of some industries and educational institutions in the area, it is characterised by high poverty levels, low levels of education large household sizes that affect access to life-enhancing facilities. Most of the young girls in the kingdom have little or no education. Oghara kingdom is a patriarchal community where polygamy and early childbearing are not abhorred.

The choice of the study area was based on the observed incidence of adolescent motherhood in the kingdom. Also, there has been paucity of demographic information on many health issues, especially those pertaining to reproductive behaviour in the kingdom.

\section{METHODOLOGY}

The study adopted a survey design in order to obtain the necessary data. The selection of the design was due to twofold reasons. First, it facilitated the collection of original data necessary to realize the research objectives. Second, it was appropriate ability to collect useful data that could be quantified and reported as a representation of the real situation or characteristics in the study population (Okech et al; 2011). The study population was adolescent girls in villages in the two sub-clans of Ogharefe and Oghareki who were randomly selected through multi-stage sampling. The study relied on primary data collected using a structured interview schedule that 
contained both open ended and closed ended questions. The research instrument was pilot tested to check if the tool could collect the necessary data. The schedule contained questions on demographic and socio-economic characteristics of the respondents, circumstances around pregnancy, wealth quintiles of the parents of the respondents and men responsible for the pregnancy and place of abode. The interview schedule was translated into and administered in Urhobo the first language of the respondents by ten trained field assistants who were indigenes of the study area. In the process of gathering data, 400 respondents were interviewed with 200 respondents from each sub-clan.

The data collected were analysed first in terms of descriptive statistics to present the socio-economic characteristics of the respondents and to examine the pattern and prevalence rate of adolescent pregnancy in the study area. To assess the association between teenage pregnancy and selected socio-economic variables, chisquare tests were performed

\section{RESULTS}

\section{CHARACTERISTICS OF THE RESPONDENTS}

Table 1: Percentage of the Respondents by socio demographic characteristics

\begin{tabular}{|c|c|c|}
\hline Background characteristics & No. of respondents & Percentage \\
\hline $\begin{array}{l}\frac{\text { Age }}{13-14} \\
15-16 \\
17-18\end{array}$ & $\begin{array}{l}98 \\
124 \\
178\end{array}$ & $\begin{array}{l}24.5 \\
31.0 \\
44.5 \\
\end{array}$ \\
\hline $\begin{array}{l}\text { Education } \\
\text { None } \\
\text { Primary } \\
\text { Secondary }\end{array}$ & $\begin{array}{l}287 \\
81 \\
32 \\
\end{array}$ & $\begin{array}{l}71.8 \\
20.0 \\
8.00 \\
\end{array}$ \\
\hline $\begin{array}{l}\text { Religion } \\
\text { Christianity } \\
\text { A.T.R }\end{array}$ & $\begin{array}{l}389 \\
11 \\
\end{array}$ & $\begin{array}{l}97.3 \\
2.7 \\
\end{array}$ \\
\hline $\begin{array}{l}\text { Working status } \\
\text { Not working } \\
\text { Working }\end{array}$ & $\begin{array}{l}327 \\
73 \\
\end{array}$ & $\begin{array}{l}81.8 \\
18.2 \\
\end{array}$ \\
\hline $\begin{array}{l}\text { Sexual initiation } \\
\text { Willingly } \\
\text { Forced }\end{array}$ & $\begin{array}{l}383 \\
17 \\
\end{array}$ & $\begin{array}{l}96.0 \\
4.0 \\
\end{array}$ \\
\hline $\begin{array}{l}\text { Ever use of family planning } \\
\text { before pregnancy } \\
\text { No } \\
\text { Yes }\end{array}$ & $\begin{array}{l}348 \\
52 \\
\end{array}$ & $\begin{array}{l}87.0 \\
13.0 \\
\end{array}$ \\
\hline $\begin{array}{l}\text { Parents wealth Quintile } \\
\text { Poor } \\
\text { Rich }\end{array}$ & $\begin{array}{l}384 \\
16 \\
\end{array}$ & $\begin{array}{l}96.0 \\
4.0 \\
\end{array}$ \\
\hline $\begin{array}{l}\text { Wealth Quintile of the person } \\
\text { responsible for the pregnancy } \\
\text { Poor } \\
\text { Rich }\end{array}$ & $\begin{array}{l}379 \\
21 \\
\end{array}$ & $\begin{array}{l}94.8 \\
5.2\end{array}$ \\
\hline $\begin{array}{l}\text { Place of abode before the } \\
\text { pregnancy } \\
\text { Lived with biological parents } \\
\text { Lived with mother } \\
\text { Lived with father } \\
\text { Lived with others }\end{array}$ & $\begin{array}{l}206 \\
87 \\
69 \\
38 \\
\end{array}$ & $\begin{array}{l}51.5 \\
21.8 \\
17.2 \\
9.5 \\
9\end{array}$ \\
\hline Total & 400 & 100.0 \\
\hline
\end{tabular}

Table 1 shows the socio-demographic characteristics of the respondents. In total, 24.5 percent of the respondents were between age 13 to 14,31 percent (15 to 16$)$ while the rest of the respondents ( 44.5 percent) were between age 17 to 18 about 71.8 percent of the respondents had no formal education, 20.3 percent had primary level education and 8.0 percent had secondary level education. About 71.8 percent of the respondents had no formal education, 20 percent had primary level education and 8 percent had secondary level education. Majority of the respondents ( 97.3 percent) were Christians. In terms of working status, almost 82 percent of the respondents were working. With regards to the initiation into sexuality/sexual life, 96.0 percent said they did it 
willingly. Only 13 percent of the respondents practiced family planning. Table one also shows that 96 percent of the respondent's parents were poor whereas 94.8 percent of the persons (men) responsible for the pregnancy were rich, 5.2 percent of them were poor. As shown in table 1, most of the respondents (51.5 percent 0 lived with their biological parents before becoming pregnant while those who lived with their mothers, fathers and others were 21.8 percent, 17.2 percent and 9.5 percent respectively.

Pattern of Adolescent Childbearing in the study Area

Table 2: Percentage of the respondents by childbearing status and socio -economic characteristics

\begin{tabular}{|c|c|c|c|}
\hline Socio-demographic characteristics & Percentage of resp & ondents & No. of respondents \\
\hline & $\begin{array}{l}\text { Who had a live } \\
\text { birth (mothers) }\end{array}$ & $\begin{array}{l}\text { Who were pregnant } \\
\text { for the first time }\end{array}$ & \\
\hline $\begin{array}{l}\frac{\text { Age }}{13-14} \\
15-16 \\
17-18\end{array}$ & $\begin{array}{l}20.1 \\
55.0 \\
71.2\end{array}$ & $\begin{array}{l}18.1 \\
10.8 \\
3.2\end{array}$ & $\begin{array}{l}98 \\
124 \\
178 \\
\end{array}$ \\
\hline $\begin{array}{l}\text { Education } \\
\text { None } \\
\text { Primary } \\
\text { Secondary }\end{array}$ & $\begin{array}{l}67.0 \\
54.1 \\
30.2\end{array}$ & $\begin{array}{l}10.3 \\
8.4 \\
5.1\end{array}$ & $\begin{array}{l}237 \\
81 \\
32\end{array}$ \\
\hline $\begin{array}{l}\text { Religion } \\
\text { Christianity } \\
\text { A.T.R }\end{array}$ & $\begin{array}{l}58.9 \\
51.2 \\
\end{array}$ & $\begin{array}{l}10.7 \\
9.1 \\
\end{array}$ & $\begin{array}{l}389 \\
11 \\
\end{array}$ \\
\hline $\begin{array}{l}\text { Working status } \\
\text { Not working } \\
\text { Working }\end{array}$ & $\begin{array}{l}54.3 \\
50.1 \\
\end{array}$ & $\begin{array}{l}6.3 \\
12.2 \\
\end{array}$ & $\begin{array}{l}327 \\
73 \\
\end{array}$ \\
\hline $\begin{array}{l}\text { Sexual initiation } \\
\text { Willingly } \\
\text { Forced }\end{array}$ & $\begin{array}{l}68.3 \\
11.5 \\
\end{array}$ & $\begin{array}{l}15.3 \\
6.5 \\
\end{array}$ & $\begin{array}{l}383 \\
17 \\
\end{array}$ \\
\hline $\begin{array}{l}\text { Ever use of family planning } \\
\text { No } \\
\text { Yes }\end{array}$ & $\begin{array}{l}68.4 \\
12.3 \\
\end{array}$ & $\begin{array}{l}15.6 \\
8.6 \\
\end{array}$ & $\begin{array}{l}348 \\
52 \\
\end{array}$ \\
\hline $\begin{array}{l}\text { Parent wealth Quintile } \\
\text { Poor } \\
\text { Rich }\end{array}$ & $\begin{array}{l}80.6 \\
15.8 \\
\end{array}$ & $\begin{array}{l}6.2 \\
11.2 \\
\end{array}$ & $\begin{array}{l}384 \\
16 \\
\end{array}$ \\
\hline $\begin{array}{l}\text { Wealth Quintile of the person resp } \\
\text { for the pregnancy } \\
\text { Poor } \\
\text { Rich }\end{array}$ & $\begin{array}{l}32.3 \\
68.7 \\
\end{array}$ & $\begin{array}{l}7.2 \\
10.4 \\
\end{array}$ & $\begin{array}{l}379 \\
21 \\
\end{array}$ \\
\hline $\begin{array}{l}\text { Place of abode } \\
\text { Lived with biological parents } \\
\text { Lived with mother } \\
\text { Lived with father } \\
\text { Lived with others }\end{array}$ & $\begin{array}{l}24.0 \\
50.4 \\
50.2 \\
61.3\end{array}$ & $\begin{array}{l}10.2 \\
13.4 \\
10.3 \\
14.2\end{array}$ & $\begin{array}{l}206 \\
87 \\
69 \\
38\end{array}$ \\
\hline Total & 56.4 & 9.8 & 400 \\
\hline
\end{tabular}

Table 2 shows that $56.4 \%$ of the respondents had children or at least a child while $9.8 \%$ were pregnant for the first time as at the time of the survey. These indicate $66.2 \%$ of the study population experience sexual intercourse and motherhood in their teen ages. This shows a high prevalence rate of teenage pregnancy in the study area. Further analysis of data indicates that teenage pregnancy in the study area was unintended as $87.3 \%$ of the respondents confessed they were not prepared for childbearing or pregnancy. This shows the low degree to which adolescents successfully control fertility in the study area. 
Table 3: Results of chi-square tests of association between adolescent childbearing and selected socioeconomic variables.

\begin{tabular}{|c|c|c|c|c|}
\hline \multirow[t]{2}{*}{ Socio-demographic Characteristics } & \multicolumn{2}{|c|}{$\begin{array}{l}\text { Percentage who have } \\
\text { begun childbearing }\end{array}$} & \multirow[t]{2}{*}{$\begin{array}{ll}\text { No. of } & \text { the } \\
\text { Respondents } & \\
\end{array}$} & \multirow[t]{2}{*}{ Chi-Square $\left(\mathrm{X}^{2}\right)$} \\
\hline & NO & YES & & \\
\hline $\begin{array}{l}\frac{\text { Age }}{13-14} \\
15-16 \\
17-18\end{array}$ & $\begin{array}{l}61.8 \\
34.2 \\
25.6 \\
\end{array}$ & $\begin{array}{l}38.2 \\
65.8 \\
74.4 \\
\end{array}$ & $\begin{array}{l}98 \\
124 \\
178 \\
\end{array}$ & $36.8^{*}$ \\
\hline $\begin{array}{l}\text { Education } \\
\text { None } \\
\text { Primary } \\
\text { Secondary }\end{array}$ & $\begin{array}{l}22.7 \\
37.5 \\
64.7 \\
\end{array}$ & $\begin{array}{l}77.3 \\
62.5 \\
35.3 \\
\end{array}$ & $\begin{array}{l}237 \\
81 \\
32 \\
\end{array}$ & $29.0 *$ \\
\hline $\begin{array}{l}\frac{\text { Religion }}{\text { Christianity }} \\
\text { A.T.R }\end{array}$ & $\begin{array}{l}30.4 \\
39.7 \\
\end{array}$ & $\begin{array}{l}69.6 \\
60.3 \\
\end{array}$ & $\begin{array}{l}389 \\
11 \\
\end{array}$ & $0.18 * *$ \\
\hline $\begin{array}{l}\text { Working status } \\
\text { Not working } \\
\text { Working }\end{array}$ & $\begin{array}{l}39.4 \\
37.7 \\
\end{array}$ & $\begin{array}{l}60.6 \\
62.3 \\
\end{array}$ & $\begin{array}{l}327 \\
73\end{array}$ & $0.0 * *$ \\
\hline $\begin{array}{l}\text { Sexual initiation } \\
\text { Willingly } \\
\text { Forced }\end{array}$ & $\begin{array}{l}16.4 \\
82.0 \\
\end{array}$ & $\begin{array}{l}83.6 \\
18.0 \\
\end{array}$ & $\begin{array}{l}383 \\
17 \\
\end{array}$ & $45.6^{*}$ \\
\hline $\begin{array}{l}\text { Ever use of family planning } \\
\text { No } \\
\text { Yes }\end{array}$ & $\begin{array}{l}16.0 \\
79.1 \\
\end{array}$ & $\begin{array}{l}84.0 \\
20.9 \\
\end{array}$ & $\begin{array}{l}348 \\
52\end{array}$ & $97.1 *$ \\
\hline $\begin{array}{l}\text { Parent wealth Quintile } \\
\text { Poor } \\
\text { Rich }\end{array}$ & $\begin{array}{l}13.2 \\
73.0\end{array}$ & $\begin{array}{l}86.8 \\
27.0\end{array}$ & $\begin{array}{l}384 \\
16\end{array}$ & $44.1 *$ \\
\hline $\begin{array}{l}\text { Wealth Quintile of the person } \\
\text { responsible for the pregnancy } \\
\text { Poor } \\
\text { Rich }\end{array}$ & $\begin{array}{l}60.5 \\
20.9 \\
\end{array}$ & $\begin{array}{l}39.5 \\
79.1 \\
\end{array}$ & $\begin{array}{l}379 \\
21 \\
\end{array}$ & $14.0^{*}$ \\
\hline $\begin{array}{l}\text { Place of abode } \\
\text { Lived with biological parents } \\
\text { Lived with mother } \\
\text { Lived with father } \\
\text { Lived with others }\end{array}$ & $\begin{array}{l}65.8 \\
36.2 \\
39.5 \\
24.5\end{array}$ & $\begin{array}{l}34.2 \\
63.8 \\
60.5 \\
75.5\end{array}$ & $\begin{array}{l}206 \\
87 \\
69 \\
38\end{array}$ & $42.0^{*}$ \\
\hline Total & 33.8 & 66.2 & 400 & \\
\hline
\end{tabular}

Table 3 shown the results of the univariate analyses of the relationship between adolescent childbearing and selected socio-economic variables: age, education working status, sexual limitation, ever use of family planning, parent wealth quintile, health quintile of the man (person) responsible for the pregnancy and place of abode of the woman before pregnancy.

Age was positively associated with adolescent childbearing. The adolescents aged 13-16 were more likely to begin childbearing compared to those 17-18 years. Respondents' education was significantly associated with childbearing. The percentage of respondents who had started childbearing decreases with increasing education. Almost 77 percent of the respondents who began childbearing had no education. About 63 percent of those began childbearing had primary education while 35.3 percent had secondary education. Sexual initiation was significantly associated with childbearing. Almost 84 percent of the respondents who began childbearing had sex with their partners willingly while 18 percent said they were forced to have sex. Use of family planning was significantly associated with childbearing. Eighty-four percent of the respondents who begun childbearing did not practice family planning while 20.9 percent of those who did not begun childbearing practiced family planning. Respondents whose parents were poor were almost thrice as likely to have started childbearing as those whose parents were rich (86.6 percent and 27 percent, respectively). The wealth quintile of the person (man) responsible for the pregnancy was also associated with childbearing. Table 3 shows that while 79.1 percent of the respondents who began childbearing had rich partners, 39.5 percent of those who did not begin childbearing had poor partners. The people the respondents stayed with before childbearing were significantly associated with childbearing. Adolescent childbearing was found significantly lower among teenagers who lived under the same roof with their biological parents (father and mother) than those who did not live with their biological parents 
under the same roof (Table 3). The table also shows that religion and working status were not associated with childbearing.

\section{DISCUSSION}

From the findings it can be concluded that adolescent childbearing is common among teenagers in Oghara Kingdom. Adolescents in the kingdom become mothers at their very early ages. The findings revealed that teenage pregnancy was positively associated with levels of education. The likelihood of becoming pregnant was lower among teens with secondary education than those with primary and no education. These findings are consistent with that of Gupta and Mahy (2003) who averred that women's secondary or higher education act as catalyst toward delayed childbearing and that of Etukudo (2015) and Kamal (2012), who concluded that women with secondary or higher education are more aware of the contraception and the need for small family size and to delay marriage. Sexual initiation was significantly associated with child bearing. This finding supported by Ekanem et.al, (2001) who observed that one of the reasons why teenagers are exposed to early and unwanted pregnancy is the tendency of these young girls to engage in exploratory behavior, their evaluation of peer social approval, lack of reliable experience of life and relative sense of invulnerability. During adolescence, teenagers may drink and experiment with drugs frequently with their friends at social gatherings and parties. Those substances greatly affect a teen's ability to logically think and carryout general thinking processes, thus increases the chances they will engage in unprotected and unsafe sexual activity which can lead to early pregnancy. (Shulkin et.al,1991). Most of these teens are exposed to pornographic films and homosexual practices. These films that are of bad taste alluringly attract these youths, thus accelerating their sexual urge. This leads to sexual acts which they willingly accept with lack of knowledge of the intended consequences (Alabi and Oni, 2007). Ever used of family planning was significantly associated with child bearing. The contraceptive use among these teenagers was very low. About $84.0 \%$ (348) of them never practiced family planning. This may have to do with the belief in the community that it is not safe to use contraceptives before starting reproductive life. That it may cause infertility. With their lack of education and knowledge about reproduction, those teens who may have multiple partners engage in unprotected sexual activities which lead to increased chances of pregnancy. The study finding revealed that the adolescents who had never used any contraceptive method were more likely to initiate childbearing at adolescent period. This finding is consistent with earlier studies conducted elsewhere (Haque 2011 and Kamal, 2012). Findings also indicate that teenagers from families of low socio-economic status are at risk of early pregnancy. This may be because their parents are unable to adequately provide their daily needs and that of the family. These may forced them to be engaged in some form of low level prostitution in order to get money to take care of themselves and their families. This is consistent with the views of Ekanem et al (2001) that teens younger than age 18 in families of low socio-economic status were prone to early sexual experience and pregnancy. The study also reveals that love for money by teenagers was also associated with childbearing especially by those whose parents are hindered by income as well as economic pressures. This is because they are always sat risk of sexual coercion and seduction by males old enough to be their fathers. This may be associated with their expectation that older men who are rich are more likely to provide for them and their families. This is consistent with the findings of Coicoiea (2009) and that of Vundule et al (2001) that parental poverty was a key factor in the high rate of adolescent pregnancy in Ecuador and among black adolescents in Cape Town, South Africa respectively. The study reveals that adolescents whose parents are not living together have more likelihood of becoming pregnant. This finding helps to confirm the conclusion of Ogunjuyigbe (2001) and Oppong (1995) that the absence of either the father or mother might lead to lack of care, lack of proper monitoring and education of child. Such situations might be exploited by older members of the community to persuade and coerce needy and helpless adolescent girls into unprotected sexual experience that can result in early and unintended pregnancy.

\section{CONCLUSION}

Adolescent pregnancy is a serious health issue in developing countries like Nigeria. This is because of its effects on teenage mothers and their babies as well as the age structure of these countries. The prevalence rate of teenage pregnancy in the study area is high and unintended. It occurs in young girls with poor level of education, and low level of contraceptive use, who come from families of low socio-economic status, whose biological parents are not staying together and among teenagers who engage in exploratory sexual activities which they willingly accept. It is therefore, crucial to target young women with accurate information on reproductive health to provide them with basic life skills and reproductive health in order to enable them to avoid early sexual activity and ultimately early childbearing. In addition, user-friendly reproductive health services should be availed to the young women who are sexually active to enable them to avoid unwanted and mistimed births. There is need to mount vigorous campaigns aimed at educating the youths of the dangers of early marriage as well as unforeseen long term effects of child motherhood. If the observed high incidence of teenage motherhood is not urgently checked it will ultimately impinge on the healthcare needs of mothers and children in the study 
area.

\section{REFERENCES}

Alabi, O. T. and Oni, I. O. (2007) Teenage Pregnancy in Nigeria: Causes, Effects and Control. International Journal of Academic Research in Business and Social Sciences 7(2):7-12

Betting, B, M. Rosato and R. Wood (1998) Teenage Mothers and the health of their children. Population Trends 93:19- 28.

Choe, M.K., S. Thapa and V. Mistra (2004) Early Marriage and early Motherhood in Nepal. Journal of Biosocial Science 37 (2): $143-62$

Corcoran, J. (1998) Consequences of adolescent pregnancy/parenting: A Review of the literature. Social Work Health care 27:49 - 67.

Ekanem, A. D.,Etuk, S. J. and Archibong, E. I (2001) Socio-economic Background of Pregnant Teenagers in Calabar. Nigeria. International Journal of Social Science and Public Policy.(4): 1, March,2001.

Etukudo, I. W. (2015) Spousal Approval, Communication and Contraceptive Behaviour in Rural Nigeria. African Journal of Midwifery and Women's Health 4(5):170-176.

Gage, A. (1995) The Social Implications of Adolescent Fertility. Paper presented at the International Union for the Scientific Study of Population - United Nations Children's Fund Seminar on Demography and Poverty, Florence, Italy.

Gerommus, A.J. and S. Korenman (1992) The Socio-economic Consequences of Teen Childbearing Reconsidered. The Quarterly Journal of Economics 107: 1188 - 1214

Gogna, M. G. Binstock; S. Fernandez; I. Ibarlucia, and I. Zamberlin (2008)

Adolescent Pregnancy in Argentina: Evidence-based recommendations for public policies. Reproductive Health Matters 16(31):192 - 201.

Goicolea (2009) Risk Factors for Pregnancy among adolescent Girls in Ecuador's Amazon Basin: A Case control study. Revist Panamericana de salud Public 26(3):221-28

Gupta, N. And M. Mahy (2003) Adolescent Childbearing in sub-Saharan Africa: can increased Schooling alone raise ages at first birth? Demographic Research, 18 (4): 93 - 106.

Haque, M.N. (2011) Levels, trends and determinants of adolescent Childbearing in Bangladesh. International Journal of Current Research 2(1):170 - 75 .

Hayes, C. (1987) Risking the Future: Adolescent Sexuality, Pregnancy and Childbearing. Washington: National Academic Press.

Ihejiamiazu, E. (1991) Preventing Maternal Mortality through improved Access to Sexual and Reproductive Health Services in Nigeria Calabar: Executive Publishers.

Kamal, S.M.S. (2012) Adolescent Motherhood in Bangladesh. Evidence From 2007 Population 39, No. 1 - 2 (Spring/Summer 2012): $63-82$.

Kappel-Man, M.M. (1977) Sex and the American Teenage: The Problems of Adolescent Sexuality and how to cope with them in today's changing World. New York: Readers Digest press.

Macweaney, L. (1985) The Facts of Life. Ibadan: African Universities Press. National Population Commission (NPC) [Nigeria] and ICF. International (2014) Nigeria Demographic and Health Survey, 2013. Abuja Nigeria and Rockville, Maryland, USA: NPC and ICF International.

Ogunjuyigbe, P.O. ( 2001) Influence of Parental Attributes on Adolescent Sexual Behaviour and Reproductive Health in Northern Nigeria. International Journal of Social Science and Public Policy. Volume 4, Number 1, March, 2001

Okech, T. C., W.W. Nelson and T. K. Mburu (2011) Contraceptive Use among Women of Reproductive Age in Kenya's City Slums.

Oladosu, G. (1989) Why Girls should not Marry Early. Life Mirrow: Nigerians First Health Newspaper, 2 (86): 1 -11 .

Oppong, C (1995) A High Price to pay for Education, Subsistence or a Place in the Job market. Health Transition Review, Supplement to Volume 5: 35-36

Population Reference Bureau (2009) Family Planning Saves Lives, $4^{\text {th }}$ edition.

Population Reference Bureau (2013) Family Planning Worldwide: 2013 Data Sheet.

Rawe, K. (2012) Every Woman's Right: How Family Planning Saves Children lives. The Save the Children Fund, UK, London.

Senderowits J. And J. M. Paxman (1985) Adolescent Fertility: Worldwide Concerns. Population Bulletin, 40 (2): $3-49$

Shulkin, J. J., Mayer, J. A. and Wessel, L. G. (1991) Effects of a peer-led AIDS Intervention with University Students. J. Ann Coll Hlth 40(2):75-79

Singh, S. (1998). Adolescent Childbearing in Developing Countries: A Global Review. Studies in Family Planning, 29:117 - 136 
Sing, S. And R. Samara (1996) Early Marriage Among Women in Countries. International Family Planning Perspectives, 22:148 - 157 and 175.

United nations Population Fund (2014) The Power of 1.8Billion.UNFPA, New York.

UNICEF (2012) Progress for Children: A report card for adolescents, No.10, April 2012

UNICEF (2006) The State of the World's children 2006

UNPF (2014): The Power of 1.8 Billion: Adolescent youth and The Transformation of the Future.

Vundule, C; Maforah, F; Jewkes, R. and Jordaan, E. (2001) Risk Factors Teenage Pregnancy Among Sexually Active Black Adolescents in Cape Town: A Case study. South African Medical Journal, 19:73-80

Wasunna, A. And K. Mohammed (2002) Low Birth Weight Babies: Socio-demographic and Obstetric Characteristics Of Adolescent Mothers at Kenyatta National Hospital Nairobi. East African Medical Journal 79 (10):543 - 56.

Wellings, K., J. Wadsworth and A. Johnson (1999) Teenage Fertility, and life chances. Rev. Reproduction 4:184 -90 .

WHO (2011a) Preventing Early Pregnancy: What the Evidence says.

WHO (2011b) Preventing Early Pregnancy and Poor Reproductive Outcomes Among Adolescents in Developing Countries. WHO Guidelines.

Wulf, D. And S. Singh (1991) Sexuality activity, Union and Childbearing among adolescent women in the Americans. International Family Planning Perspectives (17(4):137 - 144.

Zabin, L. And K. Kiragu (1998) The Health Consequences of Adolescent Sexual and Fertility, Behaviour in SubSaharan Africa. Studies in Family Planning 29 (2): 210 - 32 